\title{
Social Media and Citizen Journalism in the 2009 Iranian Protests: The Case of Neda Agha-Soltan
}

Kathleen German *

Media Studies, Miami University, Oxford, Ohio, USA

"Corresponding author: Kathleen German, Media Studies, Miami University, Oxford, Ohio, USA, Tel: 513-529-3532; E-mail: germankm@muohio.edu Rec date: Apr 09, 2014; Acc date: May 27, 2014; Pub date: June 04, 2014

Copyright: () 2014 German K. This is an open-access article distributed under the terms of the Creative Commons Attribution License, which permits unrestricted use, distribution, and reproduction in any medium, provided the original author and source are credited.

\begin{abstract}
Traditional scholarship on social movements and journalism could not envision the dramatic changes that emerging social media have brought to social uprisings. Social media technology have served to challenge cultures of control, simultaneously eroding barriers between public and private lives and promoting civic engagement of individuals in their societies. This chapter explores the implications of emerging social media employed by citizens during the disputed 2009 Iranian elections. It focuses on the use of social media including cell phones, Facebook, MySpace, Twitter, blogs, and YouTube to spread information about the death of Neda Agha-Soltan and, as a result, coalesce anti-government protestors. Starting from the case of Neda Agha-Soltan, this chapter investigates how social media have changed the role of protestors functioning as citizen journalists in social movements.
\end{abstract}

Keywords: Citizen journalists; Interability; Neda agha-soltan; Promulgation; Relative deprivation; Rhizome configuration; Secondary morality; Social media; Social movements

\section{Introduction}

Wael Ghonim, the Google executive who helped to organize the protests against Egyptian president Hosni Mubarak, remarked that "if you want to liberate a society just give them the Internet" [1]. In a sentence, Ghonim captured a key element in the recent, rapid spread of social dissent in the Middle East and especially in Iran, one of the first nations to experience social dissent in the age of new media. On June 11, 2009 Iranians went to the polls to elect a new president. In what was popularly perceived to be a fraudulent outcome, incumbent President Mahmoud Ahmadinejad won the election against favored opponents. Widespread protests immediately broke out as citizens took to the streets. In an effort to control the protestor's access to information and to shape international opinion, the Iranian government curtailed foreign reporting, limiting journalists to one news report per day and banning any participation in street activity. In the ensuing news vacuum, Iranian citizens filing stories via social media were a crucial source of information [2]. As a CNN newscaster admitted "We're dependent on Iranians reporting from inside the country for our understanding of what is happening there" [3]. Social media, including cell phones, Twitter, Facebook, MySpace, YouTube, and blogs, were critical to eye witnesses functioning as citizen journalists reporting to the world from inside Iran.

Social media have dramatically increased the access of individuals to each other and often to vast audiences in cyberspace. Clay Shirky [4] notes the result of this increased interaction: "As the communications landscape gets denser, more complex, and more participatory, the networked population is gaining greater access to information, more opportunities to engage in public speech, and an enhanced ability to undertake collective action." In the political arena as a result, societies have ignited in social protests and violence. The widespread availability of multiple social media platforms has encouraged citizens to engage in public debate and demonstrations, surprising observers with the seemingly spontaneous, random bursts of political activity.

This chapter examines the intersection of social media forms such as cell phones, Twitter, Facebook, YouTube, MySpace, and blogs with public protest, investigating the impact of emerging media on traditional conceptualizations of social protest. It posits that social media have altered the balance of power formerly dominated by government news organizations, allowing citizens greater media access to voice their positions as citizen journalists during social confrontations. At its core, social media are performative, communitybuilding, immediate, and difficult to control because of their rhizomatic or networklike configuration [5]. By resorting to social media, citizens can alter the nature of information access and foment social unrest such as the protests that occurred in Iran following the 2009 elections. To explore the implications of social media on the Iranian conflict, this chapter focuses on the death of Neda Agha-Soltan on June 20, 2009. Her death functioned as a catalyst, capturing the energy of the youth-driven protests. According to one citizen journalist, "The final moments of her tender young life leaked into the pavement of Karegeh Street today, captured by cell phone cameras, and not long after, took on new life, flickering across computer screens around the world on YouTube and even CNN" [3]. The role of social media in the confrontations between Iranian citizens and their government has implications for social movements in broader contexts as the world has witnessed in what is popularly termed "the Arab Spring."

Traditional scholarship has not kept pace with the rapid growth of emerging media and its corresponding influx of citizen journalists, especially in societies often under-represented in Western dominated international media. Beginning with the participation of citizens acting as journalists in news creation, this chapter asks what happens when centralized constraints dissolve as social media shifts the personal connections to others from geographical and semi-enduring relationships to virtual and ephemeral cyberspace communities [6,7]. This is particularly transparent during periods when traditional conventional news gathering practices are disrupted, such as during 
social protests when government crack-downs on professional journalists allow us to glimpse citizen journalists who fill the void utilizing social media. The case of Neda Agha-Sultan provides an instance when citizens used emerging media and functioned as journalists recording unfolding events for the outside world watching unfolding events through their reports. This chapter will examine the traditional models of social movements and the situation in Iran before drawing implications from this case study.

\section{Social Movements Model}

Previous scholars have examined the phenomenon of social movements and protests $[7,8]$. For example, identified the conditions that would likely result in social conflict and communication scholars Bowers et al. [9] offer insight into the hierarchy of actions that agitators and establishments use in manipulating power during confrontations. Both propose useful models for understanding the protests that swept Iran in 2009.

Headlines in major newspapers trumpeted the Arab Spring as a Twitter revolution, attributing events to emerging media. This analysis is overly simplistic and ignores predisposing conditions that must be present for revolutions to occur. In the case of Iran, the underlying conditions are outlined in an online blog E-Zan [10]: “. . . others want to call this a 'Twitter revolution' or a 'Facebook revolution,' as if zippy new technology alone had inspired the protests. But the truth is that the high turnout was the result of many years of organizational work carried out by small groups of civil rights activists and, above all, women's groups, working largely unnoticed and without much outside help. .." [10]. Ted Gurr [7] argues that social movements occur under specific conditions that predispose populations to improve their circumstances. Among those conditions is the perceived gap between the present reality and the expectation of improved conditions or "relative deprivation." In Iran, the conditions developed “. . . as a frustrated youth population confronts hopeless economies, rampant corruption, blocked politics, and indifferent, abusive state institutions" [11]. Social media, for this reason, have become one of the primary ingredients in revolutions because they allow people to compare their circumstances [12].

In Iran, the rising expectations of a bulging youthful population with access to social media technology established the milieu for protests as Lin Noueihed and Alex Warren [13] note: "Their roots lay in widespread disaffection with existing rulers, demands for greater participation in politics, rising nationalist sentiment, crop failures and economic discontent among the urban working classes. Their ideas were distributed by the burgeoning popular press, raising expectations among people whose lives had already been improved by new technology." The gap between the reality of life in Iran and the expectations of its people are also confirmed by Bill Berkeley [14] who writes, blogs ". . . vividly convey the bitter disillusionment many Iranians feel not just toward the hard-line mullahs, but toward the failed reformist project." Statistics explain the conditions for this disappointment. While literacy and education rates were extremely high in Iran, making it and Israel the best educated nations in the Middle East, unemployment hovered around $11 \%$ and $40 \%$ of the population lived below the poverty line. Seventy percent of Iranians were under the age of 30 [15]. These volatile combinations encouraged a strong sense of relative deprivation as highly educated Iranians expected improvements in their living conditions, but were frustrated by limited change and an entrenched government.
Bowers et al. [9] argue that confrontation progresses along an identifiable hierarchy of escalating challenges and responses that pit agitators against establishments. In their model, communication is critical at all stages but its function changes as the confrontations unfold. For example, in the earliest stages of social movements, the coalescence of group members requires communication that encourages individuals to find identity with the group's goals. At this stage, the nature of communication is often interpersonal [9]. As the movement gains momentum, it seeks support from outsiders in the stages of "solidification" and "polarization." This requires a different function of communication because the agitators must deal with larger, often more diverse groups of people, sometimes spread over broad geographical distances.

Prior to the appearance of social media, communication through mass media was concentrated in the hands of establishment powers. The imbalance is articulated by Clay Shirky [4]: "Disciplined and coordinated groups, whether businesses or governments, have always had an advantage over undisciplined ones; they have an easier time engaging in collective action because they have an orderly way of directing the action of their members." Centralized, efficient communication through mass media allowed governments to respond to protestors with rapid, coordinated rebuffs. For example, in the 1978-1979 Iranian Revolution, the ruling Shah controlled the major broadcast media including television and print. These media, obviously, were programmed with official, government approved messages. As a result, anti-government forces were required to rely on other, usually less effective modes of communication to share their viewpoints with large groups of unaffiliated individuals. Journalists were allowed access to alternative viewpoints mostly at the discretion of the Shah with government approval. As a result, citizens had limited influence on the content of mediated messages and the government viewpoint dominated the news and shaped world opinion [12].

The impact of social media on social protests is potentially profound. When individuals share their perceptions of dissatisfaction, the relative deprivation develops more rapidly and broadly than with conventional media controlled by the government [7]. Participation in social media enlarges individual identity by transforming entrenched personal definitions to identities with broader political dimensions [16]. This, in turn, lowers the threshold for social action [17]. As agitation develops, anti-government protestors can gather sympathizers more efficiently with less risk through social media. They can also appeal to others as the movement solidifies. Finally, they can seek social support in international circles, circumventing the gatekeepers of traditional media. Citizen journalists contact outsiders with information; they provide an archival function as witnesses to the events occurring within the country. Marc Lynch [11] draws the repercussions: "Their use of social media, especially Twitter, captivated international attention. Even if such social media played only a marginal role in organizing Iranian protests themselves, they played an outsized role in shaping global narratives. With journalists thin on the ground, the videos and tweets and blog posts out of Iran (especially in English) became arguably the most important source for information about the unfolding protests and repression."

Over the past decade, citizen journalism has spread rapidly, facilitated by social media because ordinary individuals outside the ranks of professional journalists now have direct access to vast audiences [18]. Although not a new idea, citizen journalism has recently become a more dynamic feature in news gathering and reporting because of easy access to social media outlets. Professional 
journalists are paid, often unionized, trained, and espouse a stance of neutrality in reporting the news. Citizen journalists are often untrained, unpaid, and highly partisan. However, their proximity to events and immersion in the cultural milieu gives them a unique perspective that is easy to share via social media [19]. Citizen journalists are defined by scholars as those who operate outside the realm of professional journalism and media outlets to broadcast first hand observations and opinions. According to Luke Goode [20], "Citizen Journalism includes practices such as current affairs-based blogging, photo and video sharing, and posting eyewitness commentary on current events."Sometimes the term refers to interaction with professional news outlets, as citizens participate in the gathering or dissemination of news.

The promise of the internet to challenge the establishment information monopoly has been fulfilled with the rise of citizen journalism [21]. Emerging media have become an arena for information outside traditional sources of news. The availability and variety of social media provides the catalyst for thousands of users to broadcast their personal observations to the rest of the cyber world. The quality of images captured by cell phones and other technologies continues to improve and the technology is accessible to more and more individuals. In addition, social media often bypasses the traditional gatekeepers-governments, corporations, political and financial interests, and other institutional barriers--creating a proliferation of maverick users and thereby placing even greater importance on the citizen journalist. While professional journalists are bound by professional codes of conduct, laws that protect and proscribe their reports, and intervening layers of editors and others, the citizen journalist is not bound by these constraints. As a result, their news reports can be promulgated almost instantaneously.

Why are citizen journalists important to social movements?They can provide information to help solidify the identity of social movement membership and they operate outside traditional establishment controlled media. This is especially critical when governments erect barriers to professional journalists or dictate the content of their reports [2]. The inherent layers of oversight on professional journalists regulate news stories--a form of centralized authority that usually reflects the socio-political establishment. The current social media technological explosion has introduced a decentralized environment that bypasses the layers of editors, advertisers, and others that oversee traditional media. Social media provide an environment ripe for nonprofessional citizen journalists who would undoubtedly not be included in the establishment media. This, of course, encourages the views of non-establishment groups. Citizen journalists who use blogs, Tweets, Facebook, MySpace, YouTube, and other forms of social media to engage in social movement protests have earned the label "Facebook revolutionaries" [22]. They are relatively protected because social media messages are ephemeral, shifting so rapidly that responsibility, like the source of a rumor, is difficult to trace. In the virtual world, personal identity is not subject to physical verification, so it can be created, distorted, or otherwise manipulated, serving to protect the citizen journalist. Governments have struggled to control social media and the postings of citizen journalists.

\section{The Case of Neda Agha-Soltan}

On June 20, 2009, two cell phone videos, one 40 seconds long and the other 14 second long, recorded the death of a young Iranian woman, Neda Agha-Soltan, shot during the protests [23]. The videos were circulated among millions of viewers worldwide (Video 2009). Almost seven million individuals, functioning as citizen journalists, joined the discussions through blogs, Twitters, and other online news forums that featured commentary, breaking news, background information, and of course, the video itself [3]. It was the top trending topic on Twitter by the evening of her death and during the following days [24].

The Soltan case reveals the interplay between the established government and the forces of change represented by the social protestors, many of whom recorded their positions via social media as citizen journalists. Commentators point to the role that social networking media played in the protests and researchers have confirmed that YouTube, Google and other social media were at center of the protests in Iran in 2009 [25,26]. According to Ali Anooshahr, "Arguably the most fascinating aspect of the protests is how the Internet and social media tools like Twitter circulated images and eyewitness reports to the world" [27]. It was probably the first time that social media had played a significant role in both unifying the protestors and communicating their message to the world outside Iran. As Michael Doran [1] concludes, "The spread of the Internet has provided new and effective instruments for mass political mobilization. The crowds on the streets across the Arab world were often summoned thanks to the Internet. The new media raised expectations, taught atomized individuals that they shared exactly the same thoughts and feelings, and created a mechanism for coordinating opposition activities."

Since the Iranian revolution, the concept of citizenship which has slowly crept into Iranian society since the fall of the Shah in 1979 has been augmented by the need to report concomitant with the increasing proliferation of social media. It has been an uneven path with citizen journalists like Sina Motallebi, jailed in 2003 but released after worldwide online protests (Iranian 2003). The reformist years of president Khatami expanded the practices of citizen journalism and even when the Iranian government curtailed internet use in 2009, citizens bypassed the restrictions and continued to send their messages [28].

Social media were present in the 2009 pre-election campaign, attesting to the eagerness with which Iranians communicated about public ideas [25]. Most major candidates in the presidential election had their own websites and Iran's youthful population gravitated toward the internet for news and social connections. Prior to the 2009 government crackdown, there were more than 75,000 Iranian blogs; Persian was third behind English and Chinese as the language most frequently used in the blogosphere and Iran was among the top ten nations globally in the percentage of internet users. Internet use exploded in the decade prior to the 2009 elections, eroding state monopolies on information. According to Lin Nouiehed and Alex Warren [13]: "Blog sites had mushroomed, breaking the hold of traditional newspapers with their censors and self-censors on information. A new generation of so-called 'hacktivists' brought traditional activism to the new battleground of cyberspace. The spread of social media such as Facebook and Twitter allowed millions of people who had never met to form instant communities of common interest that would play a major role when the time came. The change had been rapid and revolutionary." The internet opened up Iranian society and culture dramatically in spite of constant government censorship and the threat of punishment $[14,29,30]$.

Social media had a democratizing effect by creating a powerful sense of communal fearlessness. Iranian people turned increasingly to 
the internet for information as Nasrin Alavi writes, "It provides a safe space in which people may write freely on a wide variety of topics, from the most serious and urgent to the most frivolous." While Afshin Holavi characterizes most internet use by Iranians as personal such as sharing music, photos, and general personal experiences, "The political blogs have a power beyond their small readership because of the reverberation effect: When they break a story or simply spread a juicy rumor, it is immediately emailed to hundreds of thousands of wired Iranians and filtered to the non-wired Iranians through word-ofmouth" [30]. Paradoxically, while Iran remains a politically closed society, it is wildly open in the blogosphere where an enthusiastic community of users fiercely challenges the entrenched government structure and permits the flow of information and ideas that cannot occur in more traditional venues $[18,30]$.

Iranians living in exile and the international community also share viewpoints via the internet. Within weeks, for instance, over six and a half million blogs discussed the death of Neda Agha-Soltan with dozens of Facebook pages dedicated to Soltan and more than 50 users changing their names to Neda. One page enrolled more than 15,000 members with officers from Canada, Kuwait, Haiti, Italy, Zambia and the United States [31]. The range of posts suggests a wide variety of responses to Soltan's death. Among other examples, "United for Neda," a song recorded entirely on cell phones to pay homage to the Iranian protesters, circulated globally on social media following her death [32].

As News Media Index, a site that measures activity on the internet, noted for the week of June 22-26, almost half (47\%) of all internet traffic involved the discussion of either the deaths of Michael Jackson or the Neda Agha-Soltan, who was rapidly becoming the powerful symbol of the protest movement. And, these two stories accounted for most of the links to traditional press news sites. According to Tweet meme, which tracks links embedded in tweets across the globe, the death of Soltan represented 64\% of all news-related links (News Media Index 2009). They concluded about the function of emerging media: "They became together the latest demonstration of the power, both emotional and political, of the many-to-many nature of social media" (News Media Index 2009). The video of Soltan's death was the most viewed news video of the week on YouTube.

Initially, the Iranian government targeted only feminist and pornographer's web sites for harassment and censorship [33]. It allowed other internet users the ability to post their opinions on even forbidden topics. Operating from outdated assumptions about media, the Iranian government was caught off-guard by the initial protests. Lin Noueihed and Alex Warren [13] summarize their predicament: "Lacking the hierarchical structures of traditional organizations, the loose and leaderless networks flummoxed police, who could not identify ringleaders and did not see the young internet-savvy activists as a serious threat. Focusing on a single demand with general appeal, protestors would build coalitions that brought together the Islamist and the secular, the trade unionist and the businessman, the young and the old. The online networks that were formed were able to grow very large, very quickly but they lacked the cohesion of smaller, tight-knit networks based on face-to-face interactions over a long period, and they could vanish as quickly as they had appeared." When the government finally responded by cutting off cell phone and Internet access, protestors saw the reaction as evidence of repression and quickly found new ways to circumvent restrictions [34]. In order to maintain control of communication and retain power over their populations, regimes must develop cyber countermeasures or risk additional agitation and even capitulation, the final stage in the Bowers and Ochs social movement's model.

Following the 2009 election protests however, the government began a direct assault on both international and Iranian journalists to prevent distribution of uncensored information and unfavorable or anti-government opinions [35]. The cellular telephone network and internet were heavily censored though journalists managed to get firsthand reports to others outside Iran through the micro blogging platform Twitter [36]. Government restrictions tightened; new laws required personal websites and weblogs to be registered; postings were tracked; and, bloggers were intimidated with threats and arrests [29]. Frustrated Iranian citizens and protesters found additional ways to distribute their ideas online [37]. Doug Gross [38] reported that while activists stayed ahead of government filters, "There's been a noticeable decline already in the amount of photos and video that's coming down. . . That says that, thus far, the government is succeeding." These tactics replicate establishment responses to traditional media use in social movements [9]. However, savvy Iranians eluded the restrictions with cell phones and internet connections. This circumvention allowed citizen journalists to share videos of the death of Soltan. Within a week of the eruption of election protests, Google rolled out its Farsi translation tool enabling most internet users to interpret non-English reports of Iranian citizen journalists [26].

Eventually the Iranian government was able to hack into social media and disrupt the opposition by sowing dissension online; extracting information to identify key leaders, and disrupting attempts to organize protests [1]. It also posted official government web sites and blogs defending the election results and blaming foreign instigators for stirring up protesters. The failure of the Iranian protest or Green Movement can be attributed to multiple factors. Among them, social media cannot overcome long-term shortcomings of protest movements as Lin Noueihed and Alex Warren [13] conclude: "What made the first round of protests successful-their use of social media to communicate and agitate, their absence of clear leaders and their suspicion of the political rhetoric that had so failed them in the past-carried the seeds of their later failure. Into the void leapt older, more ingrained and more powerful forces, adroitly exploiting these divisions to further their own interests". A combination of these government tactics plus economic reforms that benefitted the middle and lower classes eventually quelled the protests and provided a prototype for other Arab nations facing similar public disruptions [39]. NBC Nightly News (27 May 2012), for example, reported that the Syrian government employed tactics learned from the Iranian government to infiltrate the internet and suppress activities of dissidents in 2012. But, there is recent evidence that the internet continues to be a political pawn as nations with vested interests in the outcome of Arab protests train individuals to evade establishment censorship [40].

In the aftermath of the 2009 social unrest, the reasons for the lack of dramatic change in Iran are summarized by Suzanne Maloney [39]: "Certainly, the spirit of protest has been beaten down by Iranian dissenters' inability to achieve meaningful results and the high price paid for each failure. Iran's unique history, its ethnic and religious divergence from its neighbors, and the central role of long-time regime insiders in leading the proto-opposition that has existed since 2009 also contribute to the surprising quiescence of the Islamic Republic." Another factor in the suppression of the opposition is the selected targeting of their leaders using social media to identify and track them. While the world's attention has been diverted by the 
events unfolding in surrounding nations, Iran's regime has effectively eliminated the opposition Green Movement leadership within Iran [39]. In this way, the Iranian government has returned to the timehonored strategy of decapitating movements that establishments have employed since the slave revolts of the Roman Empire. The Iranian government continues to stave off threats by intimidating potential opposition leadership, increasing social spending, and distributing oil profits more widely to weaken the popular reasons for revolt [39]. To date, such controls have suppressed further protests.

\section{Social Media and Social Movements}

Over a decade ago, Neil Postman [41] urged us to consider how the injection of new technologies threatens to topple stable social systems. With the rise of social media Postman's concerns are apparent; the balance of power has shifted so that governments can no longer easily restrict the flow of information by controlling the major media outlets. As the case of Neda Agha-Soltan and the subsequent protests characterizing the Arab Spring suggest, the historical pattern of social protests has been altered with the advent of social media. Several essential characteristics of social media contribute to social movements including creating an immediacy of online communities, fragmenting information, performative iterability, and the erosion of media barriers.

\section{Immediacy of internet communities}

Communities have been defined traditionally by the limitations of space; people joined together as their locations allowed them to meet and interact. However, since the rise of the internet, the idea of community, formerly conceived as a spatially-based construction, has expanded; virtual communities are fluid, constructed easily and quickly in cyberspace, hence defying geographical limitations. Instead of space, now shared beliefs, interests, and social bonds define internet communities [42-44]. Virtual communities provide the opportunity for collective identity and action by instilling a sense of camaraderie among otherwise disconnected people [16]. Values grounded in ideas such as democracy, disenfranchisement, or other ideological conditions can supercede physical barriers. Following the death of Soltan, broad participation pervaded social media discussions introducing topics such as the authenticity of the cell phone images, the identity of the shooter, the physical beauty of Neda, and speculations about the role of women in the protests. Users contributed poetry, personal tributes to Neda's bravery, and other memorials [45]. The focus of much internet chatter was concentration on the present moment and the social media user's relationship to the events. "Once the first demonstrations started, the Internet helped to spread the news like wildfire. In the past, coordinated protest on such a scale would have required a hierarchical organization. Social media, however, had eliminated the need for a leader" [1]. Social media increase immediacy by creating personal identity with the movement so engaging social media becomes an initial act of defiance.

Some scholars have characterized the new media frontier as the coming of a new orality. Walter Ong [46] posits that communication technology accounts for changing culture and consciousness in our age of "secondary orality."Secondary orality resembles its pre-print predecessor because it fosters a sense of community, concentrates on the present moment, and elevates formulaic expression. It stresses the centrality of the individual. The circulation of information via emerging media makes it possible for individuals to impress a personal presence on mass consciousness instantly even when events are distant from the individual's experience [47]. As a consequence, the individual is empowered and the barriers between private identity and public consciousness are blurred.

Another contribution of the new orality is access to a larger community via emerging media technologies. Technological changes allow us to interact with a far larger audience, perhaps more extensive than we can imagine. Such new communities of media-linked participants realize Marshall McLuhan's "global village" and Jurgen Habermas' public sphere where access is guaranteed to all citizens who assemble to express opinions [22,26]. By extension, Marc Lynch [11] refers to this as "the new Arab public sphere." This new orality introduces the potential for interactions that occur rapidly outside traditional establishment structures through the immediacy of internet communities.

\section{Fragmentation of information}

As evident from the reports of Iranian citizen journalists, social media increase the potential for fragmentation of information. Since establishments no longer monopolize mass media outlets, multiple perspectives available through multiple media are likely to occur. Contradictory information was readily apparent in account of the death of Neda Agha-Soltan. Ultimately, it might not matter whether Neda Agha-Soltan was a student of music or philosophy, or that she died in the arms of a family member, her music teacher, or a strangerall were reported by citizen journalists [48]. It might make some difference if she was a protestor pelting police with rocks or a bystander who had just left a hot car to seek the cooler air of the streets. And, verification of the source of the bullet is potentially most problematic with reports that the gunman was a rooftop sniper or a man riding past on a motorbike or, more ominously, a member of the state security forces targeting protestors [49].

Such contradictions and inconsistencies are more likely to surface as online stories are posted to serve the needs of vested interests on both sides--protestors and governments. Whether Neda is a tragic victim, an heroic martyr, or a despicable criminal may depend on the perspective of the source. For example, reports varied widely about simple facts like the number of arrests and fatalities. According to Iranian officials, between 17 and 20 people died during the monthlong protests while protesters cite several dozen deaths each day [50,51]. Almost all reports of facts reveal the discrepancy between official sources and citizen journalists [52]. The verification of citizen reporters was limited, not just by the lack of information about the news source, but by Iranians' fear of government reprisals. The lack of fact checking and editorial oversight might also account for the inconsistent information which, in turn, was picked up and circulated by other media sources [53].

\section{Iterability}

Social media are ultimately performative because individuals participate in perpetuating a seemingly endless repetition of messages [54]. By doing so, they open up new vistas for political participation that function as extensions of familial groups, blurring barriers between private life and public participation. Personal narratives are the foundation for participation in the political forum online [55]. For this reason, the story of Neda Agha-Soltan's death resonated worldwide. It encouraged empathy on a personal level as a narrative that could be retold"... without stultifying, grossly replicating, or patently reifying a single meaning, thus allowing for a cycle of 
narration and narratization that can turn the performed personal experience into a complex community one" [55]. The narrative remained dynamic, powerful, and alive through multiple reframings, reflections, and reiterations. In the end, social media do not alter the narrative, but open it up as online repetition allows individuals to embrace the message as part of a continuous loop.

This easy repetition of powerful narratives with readily available technology facilitates the formation of an opposition culture, an essential ingredient for successful social protests [1]. It encourages citizens operating safely from a distance to gather opposition supporters in much the same way that Iran expatriates rallied when presented with the images of Neda Agha-Soltan or the death of vegetable vendor Mohamed Bouazizi roused thousands of Tunisians to action or university student Khaled Said became the central symbol of Egyptian repression [1]. The crucial difference between these martyrs and others like Ogoni protestor Ken Sero-Wiwa who was executed for his leadership of the Nigerian protest movement decades earlier, was broad access to the story provided by the internet.

\section{Erosion of media barriers}

The rise of new social media alters the dissemination of information because it erodes traditional media barriers, ultimately disrupting the monopolization of media by euro-centric financial and political vested interests [56]. At the most basic level, social media bypass traditional media structures in vibrant variation and proliferation, thereby expanding the availability of content to anyone with Web access. When information is widely shared, it heightens the scrutiny of outsiders. Often the news provided by amateur citizen journalists appears more credible than the manufactured counterfeit narratives of the establishment regime [1].

Prior to the advent of social media, the death of Neda Agha-Soltan likely would have been denied or covered up. In fact, the Iranian government at first denied her death, and then claimed that the video evidence was fabricated. In spite of these attempts, the news of her death gained momentum when confirmation was circulated via social media. In similar fashion, the deaths of Mohammed Bouazizi and Khaled Said became international news and flash points for dissent within their countries just as Neda Agha-Soltan became the face of the Iranian protests. Under regime-controlled media, these deaths would have gone unreported instead of providing concrete rallying points for others.

The ability to influence political decisions by reaching mass audiences with powerful appeals alarms critics who worry that advances in technology unaccompanied by the counterbalancing checks of editorial oversight will spread misinformation and contribute to poor decision-making. Experts argue that the uninformed, one-sided information presented via social media will bring about an era of naive politics wherein young activists, deceived by misinformation from social media, will rally i support of equally misguided political action. Some policy makers predict that the power of the public encouraged by social media will "increasingly help shape our policy debates," a prospect that is frightening for many Western foreign policy experts [57]. This encourages an unhealthy armchair militancy or "slacktivism" where those with access to computers participate in revolutions passively from a distance [58]. Others argue that while such mediated messages call attention to causes initially, the momentum needed to sustain long term interest and bring about real change will be absent. So, while viral messages stir debate, they function as a fleeting cultural phenomenon that function as nothing more than a passing trend [59]. It is tempting to think of social media operating in isolation, but they do not. Traditional institutional media such as Western television and print as well as regional media like $\mathrm{Al}$ Jazeera provided saturation coverage of the Iranian elections and called international attention to the protests [53]. The extent to which social media provide reinforcement to traditional media echoing the available information, complicate the media landscape and the debate about the implications of social media.

\section{Power realignment}

While social media offer the potential for global citizenship, they may merely realign power in a new cyber-colonialism. Scholars warn that "Culture is an ecology resting on careful balances where new technologies shift these balances in unpredictable ways" [60]. Because new social media technologies allow users to transcend the limits of geography, they may realign current power structures. The impact on society is articulated by [61] who writes: "Although technologies have always been used, we are now in a quantum shift to another order of magnitude ... that reorganizes society to conform to their demand for efficiency." The very nature of human society has been reoriented as the individual gains the potential to influence the collective through the ubiquitous presence of new social media [62]. This shift introduces a potential realignment in the balance of power such as unfolded with the events of [60].

The intrusion of the emerging media technologies has contributed to the splintering of traditional audiences and reconfiguration of wired audiences, allowing participation in political discussions in immediate and complex ways. The anonymity of new media encourages participation of everyone as citizen journalists--women, youth, and formerly disenfranchised factions This change in the relationship of the individual to the community functions as a "rhizome" or network as users both consume and contribute to news, even changing its direction [63]. The rhizome-like structure of social media enables leaderless groups to organize collective action with more limited risks spread out among multiple individuals and groups mimicking the guerilla actions of more conventional militant groups.

There are additional impacts of new social media that will undoubtedly complicate the struggle among social groups vying for power. For instance, millions of people world-wide do not have the education, financial resources, language, or savvy to access the internet. As a result, they be excluded from participating in social change. This prediction is supported by the United Nations Development Program Tenth Report on the Internet and Computer Technology which found that the technological gap between wealthy and impoverished nations intensified at the end of the twentieth century [61]. Individuals who do not speak English or who reside outside the United States, Western Europe, or Japan are unlikely to have a presence in the world of new media [62].

In Iran, political power was contested broadly by young, technologically savvy urban citizenry, especially young women who play a particularly important symbolic role in Iranian culture [33,64]. For some, this participation energized their realization of political power, leading to predictions that another Iranian revolution more profound than any in the past, will energize Iran's future [65]. However, rural Iranians, older citizens, and those who did not speak English were less likely to have access to technology and, as a consequence, were excluded. The situation in Iran mirrors the world, where new technology may realign global class structure elevating those who are informed by social media and leaving behind those who 
are disconnected and, therefore, voiceless in a wired society $[66,67]$. Through the process of exclusion, emerging media may form a sort of electronic colonialism, shifting power but failing to create social equality.

Following the Iranian protests and Arab Spring that followed, some scholars have envisioned a wholesale revolution in the structure of societies as a result of fundamental changes in social interactions that stem from the internet. Alan Hedley [66], for example, argues, "what is at stake are the very thought processes of those dominated. Learning to live with emerging media may require a shift in our understanding of how we interact in our mediated worlds by influencing others-just knowing that we can individually participate directly in global discussions may shift our understanding of what constitutes knowledge and thereby power." The inherent nature of social media technology that allows for an immediacy of online communities, fragmenting information, performative iterability, and the erosion of entrenched media barriers may also require a new conceptualization of power.

\section{Conclusions}

Citing the work of French scholar Jacques Ellul, Clifford Christians [61] summarizes the technological changes in contemporary society as "more fundamental as anything the human race has experienced for thousands of years."And, though technological evolution has occurred throughout human history, the magnitude of the current changes in media promises to have a more massive impact than any previous technological development because it reorganizes societies, changing the relationship of the individual to the social structure. Information is now generated by individuals who can operate outside the controls of establishment gatekeepers. The models that helped us to understand social interactions in the age of traditional media require revision in light of new media technology.

With the shifts in the balance of power, communication citizens functioning as journalists have become indispensable to social movements. Social media are immediate, personal, widely available, and allow ordinary citizens to participate in the creation of messages in innovative ways. Gathering sympathizers in the organizational stages is more efficient and, more importantly, protestors have access to larger audiences including international audiences in ways never before imagined. The accompanying rise of citizen journalism has been facilitated by the escalation of social media.

The 2009 Iranian protests of the election results occurred within the intensely unified political space shaped by new media technologies. While the social media were not the reason, they appear to have shaped the protests by creating an immediacy of online communities, fragmenting information, performative iterability, and the erosion of media barriers. The use of social media, such as cell phones, Facebook, Twitter, blogs, and YouTube, played a role in facilitating the protests and especially in drawing international attention to them. As a result, traditional power enclaves were challenged and their authority eroded.

Past scholarship has focused on the entrenched media controlled by establishment powers. Models that described past social tensions need to be revisited and revised in an age of swiftly evolving media technology. In the new world of emerging social media, we are forced to reconsider power relationships as they are shaped by a changing landscape of emerging technologies that alter and mold access to information. The impact of the internet on all features of culture, but particularly on the structures of power, is potentially revolutionary.
Social media provide tools through which citizens and their governments struggle for power.

Perhaps the final lesson from the case of Neda Agha-Soltan comes, not in the form of the specific message that ultimately dominated Iranian politics, but rather in the longer-term affirmation of popular values. By communicating through social media, citizen journalists created the dialogue by which the results of the 2009 presidential election could be disputed. The sitting President Mahmoud Ahmadinejad represented the entrenched establishment by responding with suppression and harassment of opinion leaders, while citizen journalists affirmed the rights of protestors and rejected topdown government authority. It remains to be seen if the impact of the recent implosion among other nations of the Middle East offers Iran an opportunity to lead the currently unstable Middle Easttoward an Iranian centered region [39,63]. Citizens acting as journalists may continue to contribute to a vibrant civil society where the Arab people can freely voice their opinions and participate in wielding political power.

\section{References}

1. Doran MS (2011) The impact of new media: The revolution will be Tweeted. The Arab awakening: America and the transformation of the Middle East.

2. Randjbar-Daemi S (2010) Friend or foe? The challenges and tribulations of Iranian reporters working for Western media. Media, power, and politics in the digital age.

3. CNN (2009) Neda becomes rallying cry for Iranian protests.

4. Clay S (2011) The political power of social media. Foreign Affairs 90: 28-41.

5. Friedman L (2012) Evolution of the internet: A rhizomatic application of Darwin.

6. Hull D (2006) "Blogging between the lines." American Journalism Review.

7. Gurr RT (1970) Why Men Rebel. New Haven: Princeton University Press.

8. Smudde, Peter M (2005) Blogging, ethics, and public relations: A proactive and dialogic approach. Public Relations Quarterly 4: 34-38.

9. Bowers JW, Ochs DJ, Jensen RJ, Schulz DP (2010) The Rhetoric of Agitation and Control. Long Grove, Waveland Press Inc, Illinois.

10. E-ZAN (2009) Voice of women against fundamentalism in Iran.

11. Lynch M (2012) The Arab uprising: The unfinished revolutions of the new Middle East. Public Affairs, New York.

12. Ghosh B (2012) The new Middle East: After the Arab Spring a different world unfolds. Time Magazine, New York.

13. Lin N, Warren A (2012) The Battle for the Arab Spring: Revolution, counter-revolution and the making of a new era.

14. Berkeley B (2006) Bloggers vs. mullahs: How the Internet roils Iran. World Policy Journal 23: 71-78.

15. CIA World Factbook (2009) Iran.

16. Doug M, Tarrow S, Tilly C (2001) Dynamics of contention. Cambridge University Press, Cambridge.

17. Rheingold H (2002) Smart mobs: The next social revolution. Perseus, Cambridge.

18. Eid M, Dakroury A (2010) The Canadian media-framing of the 2009 Iranian presidential election. Media, power, and politics in the digital age.

19. Stuart A (2009) Citizen Journalism: Global perspectives. Peter Lang, New York.

20. Goode L (2009) Social news, citizen journalism and democracy. New Media and Society 11: 1287-1305.

21. Rutigliano L (2007) Emergent communication networks as civic journalism. 
Citation: German K (2014) Social Media and Citizen Journalism in the 2009 Iranian Protests: The Case of Neda Agha-Soltan. J Mass Communicat Journalism 4: 195. doi:10.412/2165-7912.1000195

Page 8 of 8

22. Acuff JM (2010) Social networking media and the revolution that wasn't: A realistic assessment of the revolutionary situation in Iran. Media, power, and politics in the digital age.

23. Kievit R (2009) Footage of dying Neda spread by Iranian refugee.

24. Video of dying Iranian woman become iconic image.

25. Gheytanchi E (2010) Symbols, signs, and slogans of the demonstrations in Iran. Media, power, and politics in the digital age.

26. Vaidhyanathan S (2011) The Googlization of everything. Berkeley: University of California Press

27. Parker CB (2009) Iran on edge: Street clashes shake Islamic regime, socia media make history.

28. Sreberny A, Khiabany G (2010) Blogistan: The internet and politics in Iran. New York: I.B. Tauris.

29. Javanshir M (2007) Who's the "we" in we are Iran? Journal of International Affairs 60: 213-219.

30. Heuvel V, Katrina (2009) Editors cut: Citizen Journalists of Iran. The Nation Online.

31. Ali S, Alexander C (2009) Neda's death highlights women's role in Iran protests (Update 3).

32. Baron D, Serena K (2009) 'United for Neda'-Mams Taylor Brings Together Iran's Superstars to Protest Iranian.

33. Millar A (2009) Women changing Iran's political terrain.

34. Nahid S (2009) In Iran, conspiracy theories flourish as regime tries to regain legitimacy.

35. Iranian journalist credits blogs for playing key role in his release from prison (2003) Online Journalism Review.

36. LeFavre J (2009) 13 dead in Tehran protests-extremely graphic video.

37. Saadadi M (2009) Iranian journalists and activists frustrated for not having access to news.

38. Gross D (2009) Iranians dodging government's internet crackdown.

39. Maloney S (2011) Iran: The bogeyman. The Arab awakening: America and the transformation of the Middle East.

40. Newton-Small J (2012) A war on two fronts. Time 179: 46-50.

41. Postman N (1992) Technopoly: The surrender of culture to technology. New York: Knopf.

42. Wellman B, Guilian M (1999) Net surfers don't ride alone: Virtual communities as communities.

43. Stavitsky A (1994) The changing conception of localism in U.S. public radio. Broadcasting \& Electronic Media, 38: 19-33.

44. Hampton K, Wellman B (2003) Neighboring in Netville: How the Internet supports community and social capital in a wired suburb. City \& Community 2: 277-311
45. Leavey P (2009) A poem for Neda Agha Soltan (1982-2009)

46. Ong WJ (1971) Rhetoric, romance, and technology. Cornell University Press, New York 2: 151-157.

47. Nagle T (1995) Personal rights and public space. Philosophy and Public Affairs 24: 83-107.

48. Afshar S (2010) Are we Neda? The Iranian women, the election, and international media. Media, power, and politics in the digital age.

49. Neda Soltan, Young woman hailed as martyr in Iran, becomes face of protests.

50. Fassihi F (2009) Inside the Iranian crackdown.

51. Heintz J (2009) Iranian police use force to break up protest.

52. Karimi N (2009) Iranian police clamp down in Tehran to thwart protest call.

53. Malek MB (2010) Cyber disobedience: Weapons of mass media destruction? Media, power, and politics in the digital age.

54. Myers WB, Rowe D (2012) The critical lede: New media and ecological balance. Text and Performance Quarterly 32: 73-77.

55. Carlin PS, Linda MP (2012) Disaster narrative emergent/cies: Performing loss, identity and resistance. Text and Performance Quarterly 32: 20-37.

56. LeVan M, Marcyrose C (2012) Of many distributions. Text and Performance Quarterly 32: 61-64.

57. Cohen N (2012) A video campaign and the power of simplicity. New York Times online.

58. Dennis M (2011) Activism vs. Slacktivism. Communications of the ACM 54: $17-19$

59. Dorrel O (2012) Kony 2012 viral video stirs debate. USA Today.

60. Rowe D, Myers WB (2012) The performative possibilities of new media. Text and Performance Quarterly 32: 59-60.

61. Christians C (1998) Foreword: Media ethics and the technological society. Journal of Mass Media Ethics 13: 67-70.

62. Miller J (1999) Globalization Widens Rich-Poor Gap, U.N. Report Says. The New York Times.

63. Zakaria F (2012) A region at war with its history. Time.

64. Jezebel M (2009) Call to arms: Neda is my daughter, I have one just like her.

65. Fields J (2009) I am Neda: Could this be the birth of a new Iranian revolution?

66. Hedley RA (1998) Technological diffusion or cultural imperialism? Measuring the information revolution. International Journal of Comparative Sociology 39: 198-211.

67. Read D (1992) The power of news: The history of Reuters. Oxford, UK: Oxford University Press. 